\title{
Difficult Talent: A Conceptual Approach to Managing Academics in Pursuit of Academic Goals
}

\author{
T. J. Sellari \\ Department of English, National Chengchi University, Taipei, Taiwan \\ Email: tsellari@nccu.edu.tw
}

Received 9 February 2015; accepted 10 March 2015; published 13 March 2015

Copyright (C) 2015 by author and Scientific Research Publishing Inc.

This work is licensed under the Creative Commons Attribution International License (CC BY). http://creativecommons.org/licenses/by/4.0/

(c) (i) 0 pen Access

\begin{abstract}
Although the diversity of forms of talent discourages generalizations about how talent should be most accurately identified, successfully attracted, and effectively managed, examination of specific fields should at least yield observations applicable to those fields. To advance the pursuit of such observations, this paper uses Herzberg's Motivation-Hygiene Theory, which separates factors causing worker satisfaction from factors causing worker dissatisfaction, to analyze trends in the management of university faculty adopted ostensibly to pursue more effectively the goals of the university. Using examples from the points of view of talent (faculty) and management (administration), the paper identifies potential difficulties in the management of university faculty that match Herzberg's factors that lead to his distinct concerns of dissatisfaction or satisfaction. The categories of Herzberg's theory associate management itself more with dissatisfaction than with satisfaction; this paper argues that, due to the nature of the talent involved, recent trends involving the active management of university faculty are unavoidably related to dissatisfaction rather than to satisfaction; furthermore, the same trends frustrate satisfaction and alter the types of satisfaction available to faculty. As a result, rather than leading merely to the identifiable exit of talent from universities, these trends lead to a change in the nature of the talent that is being attracted, and even in the very definition of the talent that is considered desirable. The result of such active management is therefore not so much an attainment of the original goals of academia, as it is an alteration of those goals to fit the methods of management. Specifically, with the introduction of modern management practices into universities and the growing intensity with which they are being applied, the goals of universities are shifting from the cultivation of knowledge-in the forms both of research and of truly educated graduates-to the manufacture of reputation. Consideration of this shift in the types of satisfaction available to university faculty will hopefully lead to further examinations of the same sort of shifts in other fields, and allow managers to question the assumptions according to which we define our goals and the ways in which we pursue them.
\end{abstract}


Keywords

\section{University Administration, Faculty, Herzberg, Motivation, Hygiene}

\section{Introduction: US University Administration in Recent History}

This paper addresses some of the difficulties of managing university staff, focusing mostly, but not exclusively, on the challenges of managing university faculty members. Recent accounts of trends in the management of universities have communicated a perception of disagreement, conflict, and friction between university administration and university faculty. Such friction is familiar enough, and one recent though perhaps extreme case reveals what is perceived as typical opposition between administration and faculty. That is the case of Idaho State University, where the president of the university combined seven colleges into five despite the opposition of 73 percent of the faculty. The president and provost were then given a vote of no confidence; the president, instead of stepping down, dissolved the university senate that had no confidence in him; a new election returned virtually the same members to the senate; the president subsequently, according to senate representatives, misrepresented to the board or ignored the resolutions and determinations of the senate [1]. Although this kind of dramatic, public back-and-forth battle between administration and faculty is not common, it nevertheless reveals tension between talent—in this case, the faculty — and those who would manage them. At heart it is the question of talent's willingness to be managed, in what ways, and by whom.

The administration of universities has long been largely the prerogative of the faculty itself. Indeed, an argument can be made that the faculty are not only the proper administrators of the university, but are the primary components of the university itself. Derek Bok, former president of Harvard University, told the story of the response that US President Dwight D. Eisenhower received at Columbia University when, during his time as president of that university, referred to the faculty as "employees" of the university. Nobel prize-winning physicist Isidore Rabi made the following reply to him: "We are not employees of Columbia University, we are Columbia University" ([2], p. 167). Donald Kennedy [3] agreed: "In the way they function, universities are, for most purposes, the faculty" (p. 23). Given this attitude, it is not surprising that university faculty are sensitive to any perceived encroachment on their academic freedom, which is in fact necessary to the proper performance of their roles within the university. The need for such freedom was expressed by Kennedy thus: "In practice, such freedom [permits] unusually creative people to lead unusually creative lives. Indeed, academic freedom connotes loose structure and minimal interference” ([3], p. 1).

The necessity for such freedom stems from the purpose of the university and the nature of the faculty's role within it. The primary activities of the university - the production and transmission of knowledge and understanding, or, as they are usually called, teaching and research—are, or should be, accomplished by the faculty, in tandem with students and assistants. The rest of the entire edifice of administrators of the modern university exists to enable the work of faculty and students to proceed. In other words, administrators enable production, but produce nothing directly. This, anyway, is the view of the faculty, or at least of a portion of it that feels at odds with its administrators. As with any group that performs a service, the contributions of university administrators that do in fact enable the work of the faculty to proceed are likely to be taken for granted when everything goes smoothly, and to be criticized when anything goes amiss.

Administrators of a university, then, are in some sense at the mercy of the faculty they are charged with administering. As a result, administrators no doubt would be grateful to be able to exercise some power of choice over the faculty, but for the most part, faculty members are chosen by other faculty members, not directly by the administration. In cases of poor performance, administrators are often rather helpless to take direct action against the poor performers, as managers in other fields might be able to do, since they have little power to hire, fire, or otherwise take action against faculty that are perceived to have performed poorly-or, for that matter, to reward those who have performed well, especially if the reward is to matter to the recipient.

Thus, difficulties emerge when administrators become, or want to act as, managers of faculty performance, for several reasons: first, as already mentioned, because faculty autonomy has long been established at universities. But there is another reason-one that has to do with the nature of the talent that a university faculty member is supposed to have: the power to think independently and the determination to pursue his or her own interests. 
These qualities are not unique to university faculty, of course, but they are essential to the performance of their responsibilities.

\section{Theoretical Background: Herzberg's Analysis of Satisfaction and Dissatisfaction}

To understand the reason for the ineffectiveness of the carrot-and-stick approach to managing talented individuals, we can turn to the motivation-hygiene theory of Frederick Herzberg, et al. [4]. Simply put, studying motivation of employees, Herzberg [4] and his colleagues realized that, when it came to job satisfaction, two separate types of factors were in play: one type gave satisfaction, and another caused dissatisfaction. The former he called motivators, and the latter, hygiene factors. As Herzberg and his colleagues explain, "When our respondents reported feeling happy with their jobs, they most frequently described factors related to their tasks, to events that indicated to them that they were successful in the performance of their work, and to the possibility of professional growth. Conversely, when feelings of unhappiness were reported, they were not associated with the job itself but with conditions that surround the doing of the job" ([4], p. 113). What exactly are these hygiene factors? Herzberg et al. say they include "supervision, interpersonal relations, physical working conditions, salary, company policies and administrative practices, benefits, and job security” ([4], p. 113) — pretty much the domain of activities of an administrator. In other words, the most likely efforts of administration are linked with possible dissatisfaction from the start. It would seem then that the best an administrator might do is to avoid causing dissatisfaction; providing satisfaction lies outside most administrative functions.

For Herzberg, motivators "satisfy the individual's need for self-actualization in his work" ([4], p. 114). Indeed, there may be a correlation between talent itself and such self-actualization. We should note that if, following Herzberg, we separate hygiene factors from motivators, money cannot be considered a motivator. Derek Bok [2], former president of Harvard, agrees: "[professors'] reasons for devoting lots of time to research or outside activity have less to do with making money than with taking on interesting assignments or enhancing their reputations” (p. 167). Bok notes that using monetary rewards can actually weaken the faculty's commitment to the university: "No system of payments can ever substitute for the genuine interest and concern of scholars, nor can it anticipate all the special efforts that a healthy university needs to elicit from its faculty. For this, one must rely on a strong, spontaneous commitment to the academic enterprise. In trying to strengthen faculty motivation, universities would make a grave mistake to respond by appealing to private gain only to weaken commitment to the institution and the traditions it stands for” (p. 167).

\section{The Nature of Academic Work}

\subsection{The Academic Enterprise}

What is the nature of the "academic enterprise" that Bok is referring to? Or, to use Herzberg's term, what are the motivators of university faculty? If, as Herzberg contends, they lie in the nature of the work itself, we have many years' worth of descriptions of what that work is. Writer, farmer, and sometime university professor Wendell Berry [5] starts from what he sees as the product of the university: "The thing being made in a university is humanity. [...] What universities, at least the publicly-supported ones, are mandated to make or to help to make is human beings in the fullest sense of those words-not just trained workers or knowledgeable citizens but responsible heirs and members of human culture” (p. 77). To Berry, faculty are charged with passing on some qualities of humanity that cannot be achieved without instruction. In this view, Berry follows John Henry Newman, who over 100 years earlier explained the kind of knowledge that he thought was the proper province and responsibility of the university: "[philosophical or liberal] knowledge is not a mere extrinsic or accidental advantage [...]; it is an acquired illumination, it is a habit, a personal possession, and an inward endowment. And this is the reason, why it is more correct, as well as more usual, to speak of the university as a place of education, than of instruction" ([6], p. 85). The distinction that Newman is making is between intellectual pursuits and "manual exercises, in the fine and useful arts, in trades, and in ways of business", which are "methods, which have little or no effect upon the mind itself, are contained in rules committed to memory, to tradition, or to use, and bear upon an end external to themselves" ([6], p. 85). According to Newman, the faculty's job is to educate students, not only by those activities normally thought of as teaching-such as lecturing, correcting papers, and giving exams - but by the living example they personify of their own education: "The general principles of any study you may learn by books at home; but the detail, the colour, the tone, the air, the life which makes it live in 
us, you must catch all these from those in whom it lives already” ([7], p. 9). In other words, to Newman, the faculty are entirely necessary to the mission of a university.

Not all those concerned with universities feel the same, however, including university presidents. A survey of American university presidents performed by Inside Higher Education [8] shows "a growing distance between faculty members and presidents”, with faculty being rated below senior administrators, trustees, deans, and department heads in terms of their helpfulness in dealing with economic challenges faced by their universities. Martin Finkelstein, a professor of higher education at Seton Hall University who is quoted in the article, claims that university presidents have removed the faculty from matters of financial responsibility, leaving them with control over academic programs but not financial decisions. As an example of this shift, he explains that the creation of new academic programs is now largely under the control of administrators, rather than faculty, as are decisions about which faculty positions to fill [8]. In other words, faculty can choose a new colleague only after an administrative decision has been made to hire someone. That prior decision is often out of the hands of the faculty.

Another former university administrator, Howard L. Smith [9], sees entrenched faculty as obstacles to meaningful improvement of their institutions: "many academics are not very receptive to change. They would rather continue deploring the plight of higher education than actually do anything about it. [...] Indeed, the higher education establishment is an important part of the very reason why problems persist instead of being resolved" (pp. 3, 7). In Smith's view, tenured faculty might simply prefer their current work environment and not want to change, regardless of the negative effects of current practices. To critics like Smith, concern for students and the reputations of universities demands change, but selfish faculty can obstruct, or try to obstruct, the revolutionary administrator, as at Idaho State University. ${ }^{1}$ Andrew Hacker and Claudia Dreifus [10] find faculty too self- centered, and the control they have over their work environment rather undemocratic: "While the rest of working Americans endure foremen and supervisors, professors often get to select their colleagues, vote on raises and promotions, and even in some instances vote out their bosses. The schools almost function for them, for their aspirations and interests” (pp. 14-15).

Here, however, we run into two related problems with this argument: first, as we have seen above, a university's goals can in large part be achieved only by or through the efforts of its faculty. It makes sense then that faculty should have significant control over those efforts. Second, it makes a difference in this context what the faculty's "aspirations and interests" are; if they match the aspirations and interests of the university community at large, there is nothing wrong with the university being centered around those aspirations and interests. It is also necessary to keep in mind that, as Derek Bok hinted above, the efforts of administrators to use incentives such as financial gain to coax faculty into complying with administrative policies or demands can destroy the faculty's commitment to the university - that is, to make the faculty more self-centered than they already are, and in a direction against the best interest of other stakeholders in the university.

\subsection{Trends in the Consequences of Conflict between Administration and Faculty}

If we accept that not all faculty have the university's best interests at heart, what can reform-minded administrators like Smith position do? In the face of intractable colleagues, it is not surprising that university administrators in his position have tried to weaken or eliminate faculty tenure, have hired adjunct faculty who are without the rights and protections of tenured faculty, and have turned to technology, which is expensive but much less fussy about self-actualization and the possible interference with it by administrators. In addition to being potential streams of additional revenue, methods such as distance-learning, videotaping lectures, on-line learning, computerized grading, etc., all reduce the number of expensive and potentially troublesome full-time faculty needed to service a particular number of credit-hours. Given the threat of such measures, is it any surprise that, as Hacker and Dreifus [10] lament, "There is a general consensus within the professoriate that administrators are a kind of class enemy and a danger, rather than facilitators of a joint enterprise” (p. 20)? By their attempts to curb faculty power and face legitimate financial challenges, administrators prove Herzberg’s classification correct, provoking dissatisfaction through their administrative choices.

In cases such as these, the source of faculty dissatisfaction is that administrators are taking not the side of the

\footnotetext{
${ }^{1}$ When considering the two sides of this argument about faculty, it is perhaps instructive to note that a former Harvard administrator like Derek Bok sees faculty as having "genuine interest and concern”, while Smith, who has been a vice president and dean at Boise State University, emphasizes faculty obstructionism. It is not impossible that, given the differences in the institutions in which they have worked, Bok’s colleagues simply have less to change.
} 
faculty, but the side of some other group of stakeholders whose interests are considered, at least by the administrators, to be more representative of the university. In effect, they are denying the centrality of faculty to the identity of the university. Whether they argue on the side of students, like Hacker and Dreifus, or on the side of the "university" like Smith, administrators who line up against faculty interests do so largely under dubious pretenses. Specifically, the pretense is that someone-sometimes administrators, sometimes students, and sometimes business leaders or public figures-knows better than the faculty how the enterprise of the university should best be pursued and improved. Of course, it is possible that faculty can be mistaken or selfish, but as a rule they are probably closer to correct about their own interests than the other groups that have input on university policies and decisions; and, as we have seen, the interests of the faculty are more likely to be aligned with the true function and purpose of the university. After all, the university is in essence a collection of individual efforts. In any case, the effects of an emphasis on students' supposed wants and requirements, as well as of an emphasis on the supposed "best interests" of the university or the society as a whole, when they are against faculty interests, have been deleterious to that function and purpose.

Perhaps the most significant damaging trend that works against university faculty is the current vogue of treating students as consumers or customers. Whether it is awarding easy grades; or providing amenities such as more comfortable dorms, more well-equipped gyms and sports facilities, and gourmet cafeterias; or designing courses and curricula that are "attractive" rather than substantive, universities end up distracting students and faculty - as well as pulling resources-from facilities and activities that are central to the universities' functions. In their recent study, Richard Arum and Josipa Roksa [11] reveal how little time outside class American university students now spend on their studies, from the nine-and-a-half hours per week of business students to the just under fifteen hours per week of science and math students (p. 79). The limited time these students average on their studies suggests that their concerns and values are not primarily academic at all, and that they might benefit from more guidance rather than more freedom of choice. Nor do market-based reforms such as privatization offer the kind of qualitative improvement that is so often touted by neoliberals; according to Arum and Roksa, "market-based educational reforms that elevate the role of students as 'consumers' do not necessarily yield improved outcomes in terms of student learning" because neither students nor parents have access to adequate information about learning at the universities they are considering, and because they do not necessarily value learning: "There is no reason to expect that students and parents as consumers will prioritize undergraduate learning as an outcome" ([11], p. 137).

What do they tend to value? The student's marketability after graduation, which is largely dependent upon the reputation of the university-its perceived quality rather than its actual accomplishment of the purposes of university education. Donald Kennedy [3] sees this attitude as one held outside the university, in contrast to the views of those inside: "Whereas those within the system generally believe that their mission is to produce graduates who can think well and work effectively, and who are able to understand, analyze, and reflect upon their culture and upon the natural world, much of the world outside sees higher education as a credentialing device: a way of estimating, for employment or other purposes, the comparative worth of individuals” (p. 7).

If administrators follow this approach, then, they are seen as acting as outsiders to the university. Rakesh Khurana, a professor in the Harvard Business School, offers strong criticism of the unquestioning acceptance of marketplace ideals in business education. On a 2002 report by the Association to Advance Collegiate Schools of Business, which stressed the marketability and potential for future earnings of the holder of the MBA degree. Khurana writes, "Nowhere in this report, authored by a committee consisting mostly of business educators, was there any discussion of education as a mission, management as a profession, or the risk to the integrity of university business schools from an uncritical adoption of a commercial self-conception” ([12], p. 343). According to Khurana, the selling of the MBA as a product destroys the real value of the degree and ignores the purpose for which it was designed; due to commercialization, the MBA degree "is not a way of certifying to outside parties that students have mastered any particular body of knowledge [...] It does not attest that an individual has been socialized to assume a particular identity and set of attendant obligations [...] In other words, whatever else the MBA may be once it has been subjected to such commercialization, it is a professional degree only in the loosest, most popular sense of the term" (p. 344). If they cannot demonstrate what their students have learned, business schools fall back on the proxy of the starting salaries of graduates to indicate the value of the degrees they offer: "with little or nothing to be gained in the marketplace from reputations for intellectual rigor or educating students in the social responsibilities of management, business school administrators are now challenged primarily to demonstrate that their schools provide access to high-paying jobs” (p. 347). Citing Nobel prize-winning 
economist Michael Spence, Khurana explains that employers' uncertainty about how to evaluate job candidates makes them use the MBA as a proxy for applicants' employability (p. 348). Tellingly, Khurana explicitly links the corporate focus on shareholders rather than on products and services to the business school focus on graduates' salaries:

The ideas of shareholder primacy and managers as the agents of shareholders stripped the occupation of management of any last vestiges of the professional identity, self-respect, or responsibility that had been attached to it through the efforts of business school founders, leaders, and faculty going back over a century to the birth of the university business school. This raised the question, among others, of whether business schools were actually 'professional schools' if business management itself was not actually a profession. And if they were not-if, instead, business schools were highly sophisticated trade schools that existed to prepare students, by and large, for careers dedicated to the sole purpose of creating private wealth, for themselves as 'agents' as well as for shareholders as 'principals'-another question that arose was whether business schools remained aligned with the mission of the university to preserve, create, and transmit knowledge to advance the public good. (p. 331)

In this use of a proxy in the face of an inability to judge, these employers resemble university administrators who use publication statistics as a proxy for academic excellence, who likewise signal by their use of a similar kind of proxy that they are unable to judge the attributes they are looking for.

In such cases, I would argue that it is not likely that subordinating or accommodating faculty purposes to the decisions of those who are less reliably informed will be an effective method of improving a university. Take the question of curriculum, for example. Should a curriculum be decided by the faculty, or should students' interests take precedence? While acknowledging that teachers are human and therefore imperfect, Wendell Berry [5] sees such academic decisions-specifically those of curriculum design—as questions involving a responsibility that rightfully belongs to faculty: "The responsibility to decide what to teach the young is an adult responsibility. When adults transfer this responsibility to the young, whether they do it by indifference or as a grant of freedom, they trap themselves in a kind of childishness. In that failure to accept responsibility, the teacher's own learning and character are disemployed, and, in the contemporary industrialized education system, they are easily replaced by bureaucratic and methodological procedures, 'job market' specifications, and tests graded by machines” (p. 86). Imperfect as they are, faculty—not students, nor business leaders, nor administrators-must be responsible for what, and whether, they teach.

\subsection{Structural Conflict between Research and Teaching}

Unfortunately, faculty, especially faculty already well-known for their research, are doing less and less of the teaching at their universities. They have become manufacturers of institutional prestige, as measured by research output, even at universities not especially famous for their research. Hacker and Dreifus [10] call the research of faculty at less prestigious universities “just compost to bulk up résumés” (p. 87), and point out that highly-paid research-oriented faculty who do not teach much make it necessary for their universities to hire adjunct faculty or use teaching assistants to make up for their lack of teaching hours. The pernicious effect of an over-emphasis on research to estimate the competence and value of faculty and universities themselves has long attracted the notice of faculty, and drawn fire from researchers. According to William F. Massy [13], in the U.S. after W.W. II, “Academic prestige and perceptions about education quality came to depend on research. [...] Applicant pools depended on prestige, and prestige depended on research. Faculty jobs also depended on research, as did a significant fraction of institutional funding-even funding provided in the name of education” (p. 7).

Critics of this trend contend that faculty's dedication to teaching and to making other contributions to their universities inevitably drops in such an academic climate. In his study of business education, Rakesh Khurana [12] recounts how the previously teaching-oriented faculty of the Harvard Business School came to emphasize research: in 1976, the school was ranked behind Stanford by MBA Magazine, and in response began to shift its emphasis from teaching to academic research, like most of the highly-rated business schools. Of course, no university will admit to discounting teaching, which, as we have seen, comprises such a big part of higher education's mission, at least conceptually. Much of the attention paid to teaching, however, is lip-service. Khurana describes the situation at Harvard Business School thus: "Claims that teaching counted for as much as research productivity were belied by the reality that research was emphasized at the expense of teaching or the development of classroom materials, as was also the case in the university at large” ([12], p. 307). From an administra- 
tor's point of view, however, it is difficult to fault the emphasis on research, since university rankings depend so heavily on research, and student enrollment, especially of the best students, may be affected by rankings. As Khurana [12] notes, due to BusinessWeek's wide influence, applicants flocked to business schools ranked highly by that magazine, and the methodology of rankings affected the schools' institutional behavior. What we see here is educational policy being influenced by a magazine; it seems no longer under the control of the faculty — or even of the administration, as administrators themselves readily saw, and questioned: according to Khurana, "some business school administrators now began suggesting that the rankings were leading to the same kinds of dysfunctional behaviors that quarterly-earnings deadlines had imposed on corporations, making them increasingly willing to sacrifice long-term organizational health for short-term gains” ([12], p. 341). Again, unhealthy practices in education were seen as mirroring harmful practices in the business world.

The easy notice that such practices draw leads to a lack of trust in administration on the part of the faculty, who realize that an important part of their purpose-teaching-is not being rewarded. There is a widespread feeling that, in the pursuit of a higher place in a questionable scale of valuation, universities have become ever more willing to sacrifice one of the activities most central to their purpose. This mania for ranking is simply an aspect of the mania for exacting quantification, even in cases where such quantification is known to be suspect. University faculty spend a lot of time evaluating data and judging the conclusions that might be drawn from it, and they therefore recognize that these rankings are partial, questionable, and even downright spurious; as a result, it is easy for them to become cynical about, and therefore resistant to, any attempt to quantify what they do.

\subsection{Spurious Quantification Exemplified}

To illustrate such a reaction to administration, I will narrate one attempt at quantification that occurred at the downtown campus of my own university, where academic assistants were asked by the university's central administration to fill in a form detailing how much time they spent, to the minute, on all of their various work activities. Being busy with more useful and urgent concerns, they waited until the afternoon the form was to be handed in, and then filled it in with best guesses; in other words, they did not take it very seriously. Indeed, it is hard to imagine how they might have been able to take it seriously at all, since they had never thought to count how many minutes per day they spent, for example, on the phone on an "average" day. In short, this attempt at evaluating their job responsibilities resulted in alienating them from the administration, since, in their eyes, an administration that takes such a pointless exercise seriously has shown very questionable judgment. The results of this exercise, however, were reportedly going to be used to "adjust" their salaries.

This was clearly a case of what Matthew Crawford [14] calls the "contrived metrics" (p. 8) of performance of white-collar workers. In Crawford's view, such contrived metrics push those subject to them away from objective standards of performance and forces them to value interpersonal relationships more than performance, even when performance is supposedly what is being measured. Such values are reflected in our system of education, as Crawford notes: "The educational goal of self-esteem seems to habituate young people to work that lacks objective standards and revolves instead around group dynamics. When self-esteem is artificially generated, it becomes easily manipulable, a product of social technique rather than a secure possession of one's own based on accomplishments" ([14], p. 158). In the case referred to immediately above, the high levels of education and professional experience led the staff involved to distrust and even feel disdain for such a misguided form of evaluation, and for the administrators who had perpetrated it. They suspected, quite rightly, that it was merely an expensive and time-consuming pretense to cut their pay and shift personnel. They asked why the administration would not just implement a new policy, without forcing them to go through a pantomime of quantitative justification. The pretense that it was a fair and rational process of evaluation might have fooled those who approved the budget and doled out awards for innovative management, but it did not fool the people with daily, hands-on experience at the very jobs under evaluation. Indeed, it is argued [15] that the academic credentials issued by universities are themselves becoming such metrics.

Such distrust and even disdain will likely continue in the face of similar attempts at "management," at least until the nature of university faculty and staff itself is changed due to patterns of hiring that depend on facility at handling such evaluations. As universities drift toward such evaluation, the faculty they attract are those who find satisfaction in fulfilling those functions; as work changes, the satisfactions it offers change along with it. As universities increasingly reward, say, grant applications rather than teaching, it will attract faculty who are good at and perhaps satisfied by such rewards. That is, in view of the ideas of the purposes and responsibilities of 
universities detailed above, of only partially qualified faculty, or at least of faculty who, despite the apparent rigor of the appointment process, have not necessarily demonstrated the qualities needed to achieve the goals of the university.

\subsection{The Effect of Hiring Decisions}

Of course, an emphasis on prestige or image as a proxy for talent is not confined to universities. Here is one example from outside the university of how a hiring decision can be made that not only does not ensure that the best person has been hired, but also redefines the position in such a way that the new qualifications make it less likely that the candidates best able to perform the job will want to apply. This case involved the hiring of the manager of the England football (soccer) team in 2006. It was a remarkable decision to many fans of English football, because it seemed readily evident that the better of two candidates had not been chosen. There was no reason related to the actual performance of the job of manager that could have led to his being chosen over the other candidate. Here is a summary of the managerial experience of the two, up to the point their candidacy was being considered (Table 1).

A list of their managerial accomplishments would suggest that O'Neill was the better choice, yet McLaren was chosen. Why? According to the Football Association chief executive at the time, Brian Barwick: "Steve [McClaren] did two fantastic interviews. He was my first choice, the FA board's unanimous choice. [...] He has an excellent reputation in the game. [...] He's been involved in big matches, has worked alongside footballers with big reputations, has experienced big competitions and this is now his big opportunity. [...] He has been involved in major international and top-class football in his role alongside Sven [Goran Eriksson, outgoing England manager], for England, and Sir Alex Ferguson, for Manchester United” [16]. In all of Barwick’s commentary, there is only one sentence about actually winning important football matches: "With Middlesbrough he won the club's first ever trophy in 2004 (the Carling Cup) and this year reached the FA Cup semi-finals. Next Wednesday they are in final of the UEFA Cup." Opponents of the choice-and there were many-suspected that it was the contrast between McLaren's jovial and media-friendly appearance and O'Neill's more abrasive style. In other words, McLaren was judged to be more presentable. One critic [17] commented, "It is also understood McClaren, who takes up his four-year post on Aug. 1, has undergone media training and been advised to lose weight while also getting his teeth fixed." If the accuracy of this comment is not discounted due to sarcasm, the choice was apparently made on appearance and presenting skills, despite O'Neill's significant edge in experience at winning football matches. Certainly, such a choice fits well with the Football Association's “core objectives" [18] at the time:

- To be seen by fans, players, managers, clubs and the government as the leading sports governing body in the world

- To lead the development of a grassroots framework which will achieve the highest levels of participation in the world

- To achieve consistent, long-term success on the field through player development at every level

- To be a leading-edge marketing organisation

- To lead and shape the debate about football at a national, UEFA and FIFA level

- To provide leading-edge service levels both internally and externally.

Table 1. Actual performance history of two managerial candidates compared.

\begin{tabular}{|c|c|c|}
\hline \multirow{2}{*}{ Category } & \multicolumn{2}{|r|}{ Manager } \\
\hline & McLaren & O’Neill \\
\hline Experience & $\begin{array}{l}\text { Middlesbrough } \\
\text { (2001-2005) }\end{array}$ & $\begin{array}{l}\text { Leicester City (1996-2000) } \\
\text { Celtic (2000-2005) }\end{array}$ \\
\hline Honors & 1 League Cup (2004) & $\begin{array}{l}2 \text { League Cups (1997, 2000) } \\
3 \text { SPL Championships (2000-1, 2001-2, 2003-4) } \\
3 \text { Scottish Cups (2001, 2004, 2005) } \\
1 \text { Scottish League Cup (2001) }\end{array}$ \\
\hline Win percentage & 38.80 & $\begin{array}{l}38.12 \text { (Leicester City) } \\
75.53 \text { (Celtic) }\end{array}$ \\
\hline
\end{tabular}


In this list of core objectives, winning football matches-the primary responsibility of the manager-is mentioned only once. All of the other objectives are about appearances ("being seen as..."), are easily achieved and evaluated ("highest levels of participation"), or require only verbiage (the rest). This example illustrates the result of an emphasis on appearances, ease of quantification, and fear of potential friction between management and the talented: the hiring of attractive candidates, those who attempt easy goals, and the frictionless; that is, to a redefinition of talent and then to a recomposition of the institution made up by those with the new set of talents. In other words, talent is redefined, and slowly the institution made up of the talented alters its complexion and sensibility. The sensitivity to outside concerns shown by the objectives regarding phrases like "to be seen" and "marketing" and "lead and shape debate" is, like sensitivity to effects on stock prices of a firm, an indicator that allowing first-class performance in the primary field (in this case, in football) is not perceived by the participants to be the first priority at all [19].

Especially for publicly-funded universities, evaluation consists of proving that a university does what it does, to people who do not understand what it does, and this situation leads administrators to focus on the semblance of quality rather than quality itself. The key difference between the evaluation of a football manager and the evaluation of a university faculty member is that the performance of the former is easily quantified in wins and losses. The performance of the latter, however, is difficult to quantify; as a result, publications become important to administrators precisely because they are easily quantified and therefore provide a relatively simple means of evaluation. One of the consequences of such an emphasis on research is that a university may actually be failing to fulfill its responsibility to the larger community due to its attempts to prove that it is fulfilling it. It is, as scholars have in fact recognized, a failure of the university to communicate with the larger community in which and for whose good it exists. Publication becomes more of a means of career advancement than a means of increasing the public good.

\section{Conclusions: Suggested Principles for the Academy}

In order to conclude, of course I would like to offer some concrete steps for university administrators to take in order to begin to turn universities back to their real purposes. Naturally, no one who has had a genuine university education can responsibly claim to have all the answers to the varied challenges that universities face. Below are some general guidelines for administrators to consider that are based on the line of reasoning of this paper. These guidelines may help universities to relocate their purposes and orient themselves toward the goals for which they were founded.

1) We should accept the fact that universities are expensive, and that they cannot be run like businesses without distorting the purposes for which they were founded. We should disbelieve the false promise that costs on faculty, books and other sources of information, and equipment (except for computer software) can be substantially lowered without a corresponding drop in quality.

2) Student should not be treated as customers, especially not (necessarily) as informed ones.

3) Faculty should be allowed substantial control over how available money is spent. They should also be held accountable for such spending, but not to those who do not really understand the function of a university.

4) If faculty members are going to be expected to be leaders, their leadership potential must be one of the qualities evaluated when they are hired.

5) The university must communicate its purpose to the public in order to avoid inaccurate criticism of its performance. Parents, students, and other stakeholders in higher education should be brought to understand the function of universities and the faculty within them.

6) Quantitative measurement should be kept in its proper place: as an indicator that questions must be asked and more detailed answers searched for, not as an answer in itself. Quantitative evaluation should never replace qualitative evaluation.

7) Administrators should be sufficiently expert in an academic field to have the confidence to evaluate the performance of faculty members without recourse to empty statistical analysis that can be gamed.

8) Teaching should be the primary concern of universities, especially at the undergraduate level, and faculty should be evaluated accordingly.

In short, I would urge that university administrators encourage faculty to return as much as possible to the work of the universities. Herzberg warned that

the loss of the direct meaning of work [...] poses a real danger of an inflexible and uncreative society that will 
be unable to react adequately to the stresses posed by an always demanding world. If the major rewards in our society are hygienic, if conditions not related to the actual conduct of work are the major sources of satisfaction, there is little motivation for the fulfillment of the highest potential in the work of each individual. When such a society has to cease living off the fat of earlier creativity, it may very well suffer the fate undergone by earlier societies now no longer in existence. ([4], p. 131)

While I do not feel such an apocalyptic tone is warranted, I nevertheless agree with the general tenor of his warning. To some degree, we can fake rankings, but we cannot fake for long the actual abilities of future students to read, write, and reason. As Herzberg noted, such abilities must start from the top down, and he called for administrators and managers to accept "the burden of a more difficult task of evaluation and of control than is true under a rigid and bureaucratic system. Instead of laying down rigid rules and demanding that these rules be followed, a supervisor would have to trust his ability to discriminate good end results from bad end results" ([4], p. 138). In the case of universities, the good results have already been enumerated by Donald Kennedy [3]: to teach, to mentor, to serve the university, to discover, to publish, to tell the truth, to reach beyond the walls, and to change. University administrators interested in pursuing these purposes could do worse than following Herzberg's advice.

\section{References}

[1] Fish, S. (2011) Faculty Governance in Idaho. The New York Times. http://opinionator.blogs.nytimes.com/2011/06/06/faculty-governance-in-idaho/

[2] Bok, D. (1993) The Cost of Talent: How Executives and Professionals Are Paid and How It Affects America. Free Press, New York.

[3] Kennedy, D. (1997) Academic Duty. Harvard University Press, Cambridge.

[4] Herzberg, F., Mausner, B. and Snyderman, B.B. (1967) The Motivation to Work. 2nd Edition, John Wiley and Sons, New York.

[5] Berry, W. (1987) Home Economics. North Point, San Francisco.

[6] Newman, J.H. (1996) The Idea of a University. In: Turner, F.M., Ed., The Idea of a University, Yale University Press, New Haven and London.

[7] Newman, J.H. (2001) Rise and Progress of Universities and Benedictine Essays. University of Notre Dame Press, Notre Dame.

[8] Lederman, D. and Jaschik, S. (2011) Perspectives on the Downturn: A Survey of Presidents. https://www.insidehighered.com/news/survey/perspectives-downturn-survey-presidents

[9] Smith, H.L. (2009) Taking Back the Tower: Simple Solutions for Saving Higher Education. Praeger, Westport, CT and London.

[10] Hacker, A. and Dreyfus, C. (2010) Higher Education? How Colleges Are Wasting Our Money and Failing Our Kids-And What We Can Do About It. Times Books/Henry Holt, New York.

[11] Arum, R. and Roksa, J. (2011) Academically Adrift: Limited Learning on College Campuses. University of Chicago Press, Chicago and London.

[12] Khurana, R. (2007) From Higher Aims to Hired Hands: The Social Transformation of American Business Schools and the Unfulfilled Promise of Management as a Profession. Princeton University Press, Princeton and Oxford.

[13] Massy, W.F. (2003) Honoring the Trust: Quality and Cost Containment in Higher Education. Anker, Bolton.

[14] Crawford, M. (2009) Shop Class as Soulcraft: An Inquiry into the Value of Work. Penguin, London.

[15] Labaree, D. (1997) How to Succeed in School without Really Learning: The Credential Race in American Education. Yale University Press, New Haven.

[16] BBC (2006) McClaren Named as England Manager. http://news.bbc.co.uk/sport2/hi/football/internationals/4969592.stm

[17] Davies, C. (2006) Bungling F.A. Suits Have Gone for Second Best in McClaren. Japan Times. http://search.japantimes.co.jp/cgi-bin/sp20060507cd.html

[18] Football Association (2011) http://thefa.com/TheFA/WhoWeAre/JobsatTheFA

[19] Cassidy, J. (2010) What Good Is Wall Street? The New Yorker. http://www.newyorker.com/magazine/2010/11/29/what-good-is-wall-street 